\title{
It Takes a Village
}

\section{Communicating a campus compost project as a local case study of sustainability education}

\author{
MEGAN BRASELL-JONES AND CAROLINE MCCAW
}

\begin{abstract}
Our relationship with waste has been tumultuous and at times dysfunctional, but it has come a long way. This paper outlines a project involving staff and students at Otago Polytechnic (in Dunedin, New Zealand) and traces the development of communication design systems and strategies aimed at on-campus behaviour change. Targeting the campus community, these communication strategies imply that people take personal responsibility for personal waste. The project was an opportunity for students to align their practices with the UN Sustainable Development Goals \#12 (Responsible Consumption and Production) and \#15 (Life on Land). This paper considers how a project that engages these goals, can also contribute to SDG \#4 (Quality Education). In the New Zealand context, this paper also outlines a consideration of bicultural thinking to inform outcomes.
\end{abstract}

KEYWORDS: Sustainability; Visual Communication Design; Biculturalism \& Design

\section{Sustainability as a Strategic Goal}

Over the years New Zealanders have been encouraged to manage their waste in a responsible way. One of the most enduring campaigns "Be a Tidy Kiwi" from the 1960s, uses the iconic kiwi, a bird only found in Aotearoa New Zealand and fondly adopted by New Zealanders as a colloquial term to describe themselves. Promotional material from this campaign continues to feature a friendly kiwi dutifully putting litter in a bin. While this elementary message has encouraged responsible behaviours, in 2021 we find ourselves catering to a far more complex waste management scenario. We are becoming frighteningly aware that polite litter prevention is not enough. Fortunately, there has been a paradigm shift which calls for the people of Aotearoa New Zealand to become kaitiakitanga (an indigenous Māori concept that translates to guardianship), to care for and protect our environments. This includes a move towards more restorative and collaborative practices to the benefit of all: people and planet.

Kaitiakitanga requires - like any relationship - investment at all levels, clear open communication and at times a re-examination of processes and practices. For the Otago Polytechnic in Dunedin, New Zealand, a pledge to move towards more sustainable practices on campus, is an inherent part of the Otago Polytechnic's Strategic Framework. This framework acts as a 
backbone to current and future thinking at the institution with an intention "To practice sustainably for the best of our communities and the environment $(2014$, p. 1)."

Educators continue to highlight that working sustainably, while now embedded in our collective consciousness, can't be successful without behavioural change. New Zealand sustainability educators and activists Niki Harré (2018) and Barry Law (2016) remind us that how we behave is far more important than displaying our values on the wall. Harré's focus on developing community consciousness towards a psychology of sustainability is a useful tool for helping communicate waste practices as more than individual responsibility.

The waste minimalization journey on the Otago Polytechnic campus has incrementally gone from desperately handwritten signs urging people to "please do the right thing", to waste management supported by strategic design and a focus on resource recovery. This has led to more successful approaches, particularly with Hospitality and Functions, to communicate the systems and intentions, to encourage participation and understanding. Under the guidance of a dedicated resource recovery assistant (and postgraduate student) Finn Boyle's Wormporium encompasses an industrial scale campus composting system and worm farm, along with communication strategies for campus and community users. The project has drawn contributions from different areas of the polytechnic to this experimental scheme in the hope that it will build meaningful relationships with users and encourage ongoing responsible action. It is also an example of Phronesis; of one person's intention of sharing their practical wisdom to enable others to make value decisions for the planet that supports them.

\section{It Takes a Village - working together and with worms!}

At the centre of the Otago Polytechnic's journey towards zero waste, is collaboration and shared thinking and practices. This is demonstrated by the recent Wormporium project - a campus-wide composting system. The Wormporium composting project has been sustained by working with others; student teams (Horticulture, The Food Design Institute, The Design School, Mechanical Engineering), Visual Communication Design Student (supervised by Design School staff) and her campus-based client (Finn Boyle), Sustainable Practice Advisors (Ray O'Brien \& Jen Rodgers), The Campus Student Village (Te Pā Tauira), Kim Thomas (Faculty supervisor of the team for the maintenance of the Living Campus) and Resource Recovery Assistant and Masters student (Finn Boyle). Key protagonist and overarching 'waste whisperer', Boyle notes that,

\footnotetext{
The project as a whole is about overhauling our organic waste systems on the campus. We've had composting systems operating at the Polytech for almost 10 years now, but we are going through a process now of trying to figure out how we can expand the reach and effect of the systems. The idea is that the project is designed, implemented and managed as much as possible by students - trying to engage as many students from the different backgrounds at the Polytech, to make a change around them. I'm also hoping that it will help people come to a more complex understanding of waste management - the challenges and opportunities (2020, p. 17).
}

This aim fits with one of the core values of the Otago Polytechnic (Sustainability or Kaitiakitaka); "to improve the environment through our operations" through seeking "new ideas and ways of operating" (2014, p. 15). 
Across campus, the polytechnic provides recycling bins in each building and area, and these are regularly emptied appropriately by contracted cleaners. Alongside this, the campus food waste and green waste are composted on site, through its Living Campus; an established permaculture food garden. Three staff members considered the established systems in their paper, 'A Case Study Applying Many and Reed's Model of Sustainability to Organic Waste Processing', published in Scope: Contemporary Research Topics, in 2018. Boyle, O'Brien \& Sellar note:

The organic waste that is produced at OP includes food waste, materials from teaching activities, and waste from campus operations such as maintenance. At present, all successfully diverted food waste and some other organic materials are processed through a range of composting methods overseen by the staff and learners involved in the New Zealand Certificate in Horticulture. By using a variety of processes working in parallel, the current system is highly resilient, has reasonable capacity and requires only a moderate input of labour and resources. One of the core values of this established system is its role as an educational platform - it is primarily managed by students and allows for a lot of hands-on learning (p. 52).

Building from this learner-centred approach, Boyle has continued to develop his restorative waste system so that in future it can extend beyond the polytechnic campus. His hope is that increased capacity will allow for waste to be accepted from the wider community as "a commercial compost collection service for local businesses" (Boyle, as cited in Stone, 2020, p. 17) with Otago Polytechnic as the hub of facilitation. This ambitious aim approaches the local community as a natural extension of the Polytechnic's learning community.

\section{Staff and Students - behaviour change on campus}

Although composting is just one of a plethora of environmental issues, it is one that is clearly connected to campus use. The amount of compostable waste generated on campus was the focus of an earlier stage of Boyle's investigation, which calculated "that 64 tonnes of organic waste is produced annually at OP (Otago Polytechnic)" (Boyle, O'Brien \& Sellar, 2018, p. 52). In 2020, after polytechnic-wide consultation, the composting system was renamed Wormporium. Boyle was employed to develop and maintain the growing systems, and also acts as a resource recovery assistant. As it grows, Wormporium now encompasses an industrial scale campus composting system and worm farm, along with communication strategies for campus and community users.

Although already embedded in horticulture student education, a number of opportunities existed to expand the reach and involvement of other learners on campus. It was identified that the opportunity for the hands-on involvement of learners would help to develop students' knowledge about composting practices and reflect more generally as sustainable practitioners (Otago Polytechnic - Te Kura Matatini ki Otago, 2018). At this stage the Polytechnic reframed the language used to describe the project from "organic waste management" to "organic resource recovery," thereby shifting the focus from (merely) solving a problem to utilising an opportunity for transformation and restoration, reflecting the role of compost as a nutrientrich soil additive, a gift rather than a problem. In this way, the project can be seen as nurturing 
sustainable practices in students, providing rich learning experiences, not just solving problems.

Boyle's aim to grow the system to service the local community, providing composting services for local businesses and residents can similarly be likened to a garden, where the benefits can be widely appreciated, reflecting the call to action by Harré (2018) and Law (2016) that how we behave is more important than displaying our values on the wall and this is where institutions like ours, will potentially have the most impact - through action and education.

\section{Project Brief and Design Student Involvement}

A rhizomatic element of Boyle's study was to bring others on the journey towards sustainability.

Our own involvement in this compost project was to suggest that Boyle work with design students. For all students engaging in their third year of study in Visual Communication Design, the aim is to integrate ethical frameworks that allow them to practice responsibly as a designer in bicultural Aotearoa New Zealand. To achieve this, students are matched up to real world client projects. Over an eight-week period, the client/student relationship grows in order to establish a particular design problem and negotiate solutions.

In 2020, a team of communication design students was matched up with Boyle to learn how to work with the needs of a client, understand the clients' user needs and consider creative strategies to develop a campaign. The then named, Campus Compost Company was a great fit. The student design team's investigation produced a series of related graphic outcomes including, graphic assets, typography and a colour palette. These were then presented to demonstrate the potential application of these elements for print media, film, a large-scale mural and associated design collateral. From this initial scoping project, another communication design student was engaged to produce directive yet, compelling branding and messaging to call targeted users to action and improve engagement in the waste management process. Under guidance from staff and informed by research, third-year design communication student, Courtney Forbes, used her developing knowledge of design as a tool to create an identifying mark, infographics and a visual language for the Campus Compost Company as part of its launch in late 2020. This included a name change to Wormporium.

For Forbes, this meant communication about "behavioural change regarding waste by portraying it in a new light, as fun rather than intimidating (2020)." In her brand manual she describes the identity's meaning thus:

The main goal of this visual identity is to educate and raise awareness around the Wormporium and the composting process in general, as this is a newly introduced initiative to the Polytech. Education is vital for inspiring change, as many people do not know about the value in composting.

[the] official logo of the Wormporium, combines both graphic imagery and typography to create a fun, bold and engaging representation of the compost system. The worm is a reference to the soil biota that aids the compost process, but its infinity shape also represents the ongoing cycle of this process, which essentially uses organic waste to produce organic food $(2020$, p. 1).

Part of the student designer's brief is to identity a client's brand values and project these into strategically designed visual communication. Forbes' isolated these as such:

The Wormporium is a new on-site organic waste system at Otago Polytechnic, which is dedicated to spreading the positive message that organic waste should be seen as an opportunity not a 
problem in the context of Otago Polytechnic, its staff and students, its campus and surrounding areas $(2020$, p. 2).

Forbes' identified four key brand values that reflect the project's key merits, useful for both Boyle to consolidate his thinking and actions, as well as creating a focus for ongoing communication strategies. We have paraphrased these:

Opportunity: The Wormporium presents the composting of organic waste as an opportunity, rather than a problem. It is an opportunity for people to learn more about composting and enables us to use waste in ways that gives nutrients back to both land and people. Community: Otago Polytechnic has a strong sense of our role in the community. The Wormporium should be considered as a hybrid brand of the Polytechnic, and educational in nature. It will allow others to work together in community on common goals.

Public Perspective: The Wormporium strives to change the public perceptions of composting systems, by showing composting in a fun and engaging way.

Environmental Stewardship: The Wormporium exists to provide an environmentally sustainable alternative to discarding waste into the landfill, which negatively effects both land and oceans.

\section{Bicultural Context}

New Zealand is a bicultural nation, and as such is bound by the Treaty of Waitangi to give voice and agency to indigenous Māori. Sustainability and being mindful of resource use and replenishment is a core value of the Māori worldview. For the Wormporuim project, the Otago Polytechnic's cultural 'Kaitohutohu Office' was approached to include an indigenous perspective. Through this process, Māori advisors extended a gift, the right to the use of the Māori word "Pōpopo". This translates to mean 'biodegradable' or 'decay'. It is a lovely word to say.

Forbes reflects that she consciously prioritised this word in her final brand mark as an opportunity for people to learn the word, but also to "challenge public thinking" (2020) around the use of bilingual signage that most often places the dominant language first.

\section{Project SDGs/Sustainable Practices}

As part of the culture at Otago Polytechnic, students are expected to become responsible practitioners. Currently, this includes an understanding of various models of sustainability and tools to implement sustainable thinking. Students are asked to consider, for example, the United Nations' Sustainable Development Goals to steer their creative efforts towards meaningful outcomes. The Wormporium project addresses the UN Sustainable Development Goals \#12 (Responsible Consumption and Production) by considering waste and \#15 (Life on Land) for the regenerative qualities of composting that are directly used on the green spaces, and community food gardens through their Living Campus. At the same time, by engaging in collaborative and sustainable practices through project-based learning, this approach also contributes to \#4 (Quality Education), and extends education beyond campus to consider the local community as potential learners. As well as preparing students to work in industry in a client/designer relationship, they are given the opportunity to think and practice with an eye on increasingly important relationships with the natural environment. No longer on the 
periphery, responsible design is at the forefront of preparing students to meet the challenges of the future. With this in mind, those contributing to the success of The Design School, are committed to developing quality education through embedding sustainability values, and becoming kaitiakitanga or stewards/caretakers. Though a relatively small example, the Wormporium project helps us to see and think about the role of sustainability education through hands on practices. Students are required to think beyond themselves, their grades or their own education, and take on the role of teacher and active community member. Through reconceiving the composting system as an opportunity for new growth, Forbes began a system of communicating compost as a positive story. Her design project helped to reinforce the role an education facility has within its community, allowing other members of the community to partner with education in productive ways that all benefit from. Through using fun and engaging graphics, the Wormporium strives to change the public perceptions of composting systems, and provide daily opportunities for behaviours that support environmental stewardship, and nurturing practices.

\section{Conclusion - Fertile ground for learning}

Like composting, holistic education includes as many as possible stakeholders in the learning journey. Learners from Mechanical Engineering, Food Design, Horticulture and Communication Design have taken part in this composting system, but the latter have designed messages aimed at being even more inclusive. This has enabled creative and fertile ground for learner behavioural change.

The experimental composting scheme has drawn contributions from different areas of the polytechnic in the hope that it will build meaningful relationships with users and encourage ongoing responsible action. This includes a connection to indigenous voices through language and shared interest in taking responsibility for the health of the land.

Various educators have made it clear that sustainable practice, while now in our (New Zealander's) collective consciousness, cannot happen without behavioural change.

It will involve applying sustainable thinking to real life scenarios, with a collaborative approach. Knowledge was developed, shared and then considered as a possible visual communication solution for the benefit of others. It has also worked to increase visibility of existing waste management systems. The challenge now will be to continue the work that has been started and to share any successes with a wider audience. This step will help keep up the momentum of more effective waste management but also maintain conversations around zero waste and a journey towards regenerative practices. Changing human behaviour is not always easy but increasingly urgent (and indeed inevitable) if we are to take responsibility for the problems associated with waste. We would like to conclude by asking you to consider local opportunities on your campus to expand learning, in ways that address waste minimization, acts inclusively and creates long term value.

\section{Literature}

Birnie, C., Elwood, K., Henry, St., Mann, S., \& Pawlowski, I. (2009). A Simple Pledge: Towards Sustainable Practice. Dunedin, New Zealand: Otago Polytechnic. Retrieved from https://www.op.ac.nz/assets/Uploads/Sustainability/47f55b760a/A-Simple-Pledge-Document.pdf 
Boyle, F., O'Brien, R. \& Sellar, S. (2018). A Case Study Applying Many and Reed's Model of Sustainability to Organic Waste Processing. In Scopes: Contemporary Research Topics, Sustainable Practice, (6), 51-59.

Brasell-Jones, M. (2017). Sustanimal: A Reflection on Collaboration, Visual Communication and Waste Management. Scope: Contemporary Research Topics, Learning \& Teaching, Sustainability, (4), 46-52.

Forbes, C. (2020). Pōpopo Wormporium: Brand Guidelines \& Visual Identity. Pp. 1-18.

Forbes, C. (2020). Wormporium. Retrieved from https://www.courtneyforbesdesign.com/\#/053204149098/

Harré, N. (2018). Psychology for a Better World: Working with people to save the planet. Auckland, New Zealand: Auckland University Press.

Law, B. (16 August, 2016). Workshop given at the School of Design, Otago Polytechnic, Dunedin.

Otago Polytechnic. (2014). Otago Polytechnic Strategic Directions 2015-2017. Dunedin, New Zealand: Otago Polytechnic. Retrieved from https://www.op.ac.nz/assets/our-publications/Otago-Polytechnic-Strategic-Directions-2015-2017.pdf

Otago Polytechnic. (2014, February). Sustainable Practice Strategic Framework 2013-2015. Dunedin, New New Zealand: Otago Polytechnic. Retrieved from https://www.op.ac.nz/assets/PDFs/2013-Strategic-Goals/d414d858e4/Sustainability-SF-2013-Posted-on-Insite-17April-2013.pdf

Otago Polytechnic. (2020). Help us make a better world by contributing to a hot new project - OP's new community composting station! Retrieved from https://www.op.ac.nz/aboutus/news-and-events/item/6805

Stone, J. (2020, September). Interview with Finn Boyle on Wormporium. Made (1), p. 17. Dunedin.

Te Komiti Kawanataka. (2006, updated 2012). Te Kura Matatini ki Otago: Maori Strategic Framework 2012 - 2014. Dunedin, New Zealand: Otago Polytechnic. Retrieved from https://www.op.ac.nz/assets/K04298_2020-MaoriStrategicFramework_WEB.pdf 